\title{
LUMINESCENT METAL CLUSTERS. SPECTROSCOPIC PROPERTIES AND X-RAY STRUCTURE OF A TRINUCLEAR GOLD(I) COMPLEX CONTAINING BIS(DIPHENYLPHOSPHINO)METHANE AND PHENYLACETYLIDE
}

\author{
CHI-MING CHE* and HON-KAY YIP
}

Department of Chemistry, The University of Hong Kong, Pokfulam Road, Hong Kong

and

\section{WEI-CHUNG LO and SHIE-MING PENG}

Department of Chemistry, National Taiwan University, Taipei, Taiwan

(Received 28 July 1993; accepted 26 October 1993)

\begin{abstract}
The reaction of $[\mathrm{Au}(\mathrm{C} \equiv \mathrm{CPh})]_{\infty}$ with dppm [bis(diphenylphosphino)methane] in ethanol gave $\left[\mathrm{Au}_{3}\left(\mu_{2}-\mathrm{dppm}\right)_{2}(\mathrm{C} \equiv \mathrm{CPh})_{2}\right]\left[\mathrm{Au}(\mathrm{C} \equiv \mathrm{CPh})_{2}\right]$. The complex has been characterized by $\mathrm{X}$-ray crystal analysis. The structure consists of a trinuclear $\left[\mathrm{Au}_{3}\left(\mu_{2}-\mathrm{dppm}\right)_{2}\right.$ $\left.(\mathrm{C} \equiv \mathrm{CPh})_{2}\right]^{+}$cation with the three gold atoms arranged in an isosceles triangle. The intramolecular $\mathrm{Au} \cdots A \mathrm{Au}$ separations are 3.083(2) and 3.167(2) $\AA$. At room temperature, the $\left[\mathrm{Au}_{3}\left(\mu_{2}-\mathrm{dppm}\right)_{2}(\mathrm{C} \equiv \mathrm{CPh})_{2}\right]\left[\mathrm{Au}(\mathrm{C} \equiv \mathrm{CPh})_{2}\right]$ complex is photoluminescent in the solid state and in solution.
\end{abstract}

Polynuclear $d^{10}$ complexes have been shown to possess intriguing photophysical and photochemical properties. ' Of particular interest to us are the polynuclear gold(I) complexes, for many of them are found to exhibit intense and long-lived solution emission at room temperature. ${ }^{1-g}$ In our laboratory, we have synthesized several luminescent polynuclear gold(I) complexes by using polydentate phosphines and isocyanides. ${ }^{\mathrm{lc}-\mathrm{g}}$ Recent interest in organogold complexes in areas such as material science $^{2}$ and organic synthesis ${ }^{3}$ prompted us to investigate the excited state properties of gold(I)acetylide complexes such as $\left[\mathrm{Au}_{2}\left(\mu_{2}\right.\right.$-dppe $\left.)(\mathrm{C} \equiv \mathrm{CPh})_{2}\right]$ $\left[\mathrm{dppe}=\right.$ bis(diphenylphosphino)ethane]. ${ }^{4} \mathrm{We}$ anticipate that it is feasible to assemble organogold units by employing polydentate phosphine ligands. Herein is described the X-ray crystal structure and spectroscopic properties of a trinuclear $\mathrm{Au}^{\mathrm{I}} \mathrm{com}$ plex, $\quad\left[\mathrm{Au}_{3}\left(\mu_{2} \text {-dppm }\right)_{2}(\mathrm{C} \equiv \mathrm{CPh})_{2}\right]\left[\mathrm{Au}(\mathrm{C} \equiv \mathrm{CPh})_{2}\right]$ [dppm $=$ bis(diphenylphosphino)methane].

*Author to whom correspondence should be addressed.

\section{EXPERIMENTAL}

\section{Synthesis}

A solution of $[\mathrm{Au}(\mathrm{C} \equiv \mathrm{CPh})]_{\infty}(0.1 \mathrm{~g})$ and excess dppm $(0.1 \mathrm{~g})$ in ethanol $\left(\sim 30 \mathrm{~cm}^{3}\right)$ was heated at $\sim 60^{\circ} \mathrm{C}$ until the solution became clear. The solution was filtered and a yellow solid appeared after reducing the solvent volume. The product was crystallized by diffusing diethyl ether into a dichloromethane solution.

\section{Instrumentation}

UV-vis absorption spectra were recorded with a Milton Roy 3000 array spectrophotometer. Emission spectra were measured with a Spex Fluorolog2 Model F III Al fluorescence spectrophotometer. Emission lifetimes were measured with a laser flash photolysis set-up equipped with a Quanta-Ray DCR-3 Nd:YAG pulsed laser and a Tektronix 2430 digital transient recorder. 
$X$-ray structure determination of $\left[\mathrm{Au}_{3}\left(\mu_{2}-\mathrm{dppm}\right)_{2}\right.$ $\left.(\mathrm{C} \equiv \mathrm{CPh})_{2}\right]\left[\mathrm{Au}(\mathrm{C} \equiv \mathrm{CPh})_{2}\right]$

Crystals suitable for diffraction analysis were obtained by diffusing diethyl ether into a dichloromethane solution. A crystal was mounted on a glass fibre. Diffraction measurements were carried out on an Enraf-Nonius CAD4 fully automated four-circle diffractometer. The unit cell was determined and refined using setting angles of 24 randomly selected reflections, with angles in the range of $17.24-24.7^{\circ}$, obtained by using the CAD4 automatic search, centre, index and least-square routines. All data reduction and structure refinements were performed with the NRCC-SDP-VAX packages. The structure was solved by the Patterson method and refined by least-squares ; all non-hydrogen atoms of the cation and gold atom of the anion were refined with anisotropic thermal parameters. There are serious disorders of the bisacetylide gold(I) anion; the gold atom is about $0.9 \AA$ off the $C_{2}$-axis. Attempts to refine the structure with the space group $\mathrm{C}_{\mathrm{c}}$ were unsuccessful due to the high correlation between the atoms of the cations. The crystal data and data collection parameters are summarized in Table 1 . Selected bond distances and angles are given in Table 2. Positional parameters and thermal parameters are given as supplementary material.

\section{RESULTS AND DISCUSSION}

Figure 1 shows a perspective view of the $\left[\mathrm{Au}_{3}\left(\mu_{2}-\right.\right.$ $\left.\mathrm{dppm})_{2}(\mathrm{C} \equiv \mathrm{CPh})_{2}\right]^{+}$cation, which possesses the crystallographic $C_{2}$ symmetry. The structure is composed of an isosceles triangle of gold atoms with $\mathrm{Au}-\mathrm{Au}$ separations of 3.083(2) and 3.167(2) $\AA$. These $\mathrm{Au}-\mathrm{Au}$ distances are similar to those found in other phosphine-bridged gold(I) complexes such as $\left[\mathrm{Au}_{2}\left(\mu_{2} \text {-dppm }\right)_{2}\right]\left(\mathrm{BF}_{4}\right)_{2}{ }^{1 \mathrm{~d}}$ and $\left[\mathrm{Au}_{3}\left(\mu_{3} \text {-tpm }\right)_{2}(\mathrm{Cl})\right]^{2+}$ $[\mathrm{tpm}=\text { tris(diphenylphosphino)methane }]^{\mathrm{le}}$. The $\mathrm{Au}(2)$ atom is coordinated with two phosphorus atoms each from the two bridging dppm ligands in a distorted linear fashion, with a $\mathrm{P}(2)-\mathrm{Au}(2)-\mathrm{P}(2 \mathrm{a})$ angle of $166.4(3)^{\circ}$. On the other hand, both $\mathrm{Au}(1 \mathrm{a})$ and $\mathrm{Au}(1)$ are coordinated to one phosphorus atom from dppm and phenylacetylide in such a way that the two phenylacetylides are opposing each other. The coordination geometries of $\mathrm{Au}(1)$ and $\mathrm{Au}(\mathrm{la})$ are almost linear, with a $\mathrm{P}(1)-\mathrm{Au}(1)-\mathrm{C}(1)$ angle of $174.5(9)^{\circ}$. The anion $\left[\mathrm{Au}(\mathrm{C} \equiv \mathrm{CPh})_{2}\right]-$, which is heavily disordered, is linear in geometry.

Figure 2 shows the UV-vis absorption spectrum of $\left[\mathrm{Au}_{3}\left(\mu_{2}-\mathrm{dppm}\right)_{2}(\mathrm{C} \equiv \mathrm{CPh})_{2}\right]\left[\mathrm{Au}(\mathrm{C} \equiv \mathrm{CPh})_{2}\right]$ measured in acetonitrile. The spectrum exhibits an intense absorption band at $276 \mathrm{~nm}\left(\varepsilon_{\max }=6.9 \times\right.$ $\left.10^{4} \mathrm{M}^{-1} \mathrm{~cm}^{-1}\right)$. This absorption band is similar to the metal $(\mathrm{Au})$ perturbed intraligand transition of

Table 1. Crystal data

\begin{tabular}{ll}
\hline Formula & {$\left[\mathrm{Au}_{3} \mathrm{P}_{4} \mathrm{C}_{66} \mathrm{H}_{54}\right]^{+}\left[\mathrm{AuC}_{16} \mathrm{H}_{10}\right]^{-}$} \\
Crystal system/space group & monoclinic/C2/c \\
$M$ & 1961.33 \\
$a(\AA)$ & $22.827(12)$ \\
$b(\AA)$ & $13.170(3)$ \\
$c(\AA)$ & $25.398(5)$ \\
$\beta\left({ }^{\circ}\right)$ & $108.56(3)$ \\
$V\left(\AA^{3}\right)$ & $7239(4)$ \\
$D_{\text {calc }}\left(\mathrm{g} \mathrm{cm}^{-3}\right)$ & 1.800 \\
$Z$ & 4 \\
$F(000)$ & 3728 \\
Temperature $(\mathrm{K})$ & 298 \\
Data collection parameters & \\
$\lambda\left(\mathrm{Mo}-K_{\alpha}\right)(\AA)$ & 0.7107 \\
Scan method & $2 \theta-\theta$ \\
Scan range & $2(0.80+0.35 \tan (\theta))$ \\
Scan speed ( ${ }^{\circ}$ min & $-1)$ \\
Crystal size (mm) & $2.35-8.24$ \\
Transmission factor : max, min & $0.30 \times 0.40 \times 0.50$ \\
Number of unique reflections & $1.000,0.608$ \\
Number of atoms and parameters & 4720 \\
$\quad$ refined & 77,385 \\
$\Delta / \sigma_{\text {max }}$ & \\
$R, R_{w}$ & 1.3961 \\
G. O. F. & $0.068,0.051$ \\
\hline
\end{tabular}


Table 2. Selected bond lengths $(\AA)$ and angles $\left({ }^{\circ}\right)$ of $\left[\mathrm{Au}_{3}\left(\mu_{2}-\mathrm{dppm}\right)_{2}\right.$ $\left.(\mathrm{C} \equiv \mathrm{CPh})_{2}\right]\left[\mathrm{Au}(\mathrm{C} \equiv \mathrm{CPh})_{2}\right]$

\begin{tabular}{llll}
\hline $\mathrm{Au}(1)-\mathrm{Au}(2)$ & $3.167(2)$ & $\mathrm{Au}(1)-\mathrm{Au}(1 \mathrm{a})$ & $3.083(2)$ \\
$\mathrm{Au}(1)-\mathrm{P}(1)$ & $2.293(6)$ & $\mathrm{Au}(1)-\mathrm{C}(1)$ & $2.01(3)$ \\
$\mathrm{Au}(2)-\mathrm{P}(2)$ & $2.328(6)$ & & \\
& & & \\
$\mathrm{Au}(1 \mathrm{a})-\mathrm{Au}(1)-\mathrm{Au}(2)$ & $60.88(3)$ & $\mathrm{Au}(1)-\mathrm{Au}(2)-\mathrm{Au}(1 \mathrm{a})$ & $58.25(5)$ \\
$\mathrm{P}(1)-\mathrm{Au}(1)-\mathrm{C}(1)$ & $174.5(9)$ & $\mathrm{P}(2)-\mathrm{Au}(2)-\mathrm{P}(2 \mathrm{a})$ & $166.4(3)$ \\
$\mathrm{Au}(2)-\mathrm{Au}(1)-\mathrm{P}(1)$ & $81.0(2)$ & $\mathrm{Au}(2)-\mathrm{Au}(1)-\mathrm{C}(1)$ & $104.4(9)$ \\
$\mathrm{Au}(1)-\mathrm{Au}(2)-\mathrm{P}(2)$ & $92.1(2)$ & $\mathrm{Au}(1)-\mathrm{Au}(2)-\mathrm{P}(2 \mathrm{a})$ & $99.8(2)$ \\
$\mathrm{Au}(1)-\mathrm{C}(1)-\mathrm{C} 2)$ & $174(3)$ & $\mathrm{P}(1)-\mathrm{C}-\mathrm{P}(2)$ & $113.9(11)$ \\
\hline
\end{tabular}

$\mathrm{PhC} \equiv \mathrm{C}^{-}$found in the absorption spectra of $\left[\mathrm{NBu}_{4}\right]\left[\mathrm{Au}(\mathrm{C} \equiv \equiv \mathrm{CPh})_{2}\right]$ and $\left[\mathrm{Au}(\mathrm{C} \equiv \equiv \mathrm{CPh})\left(\mathrm{PPh}_{3}\right)\right]$, ${ }^{5}$ and is assigned to it accordingly. Apart from the $\mathbf{2 7 6}$ $\mathrm{nm}$ band, there is an intense absorption shoulder $\left(\varepsilon=10^{4}-10^{3} \mathrm{M}^{-1} \mathrm{~cm}^{-1}\right)$ at $315-375 \mathrm{~nm}$. This absorption feature is absent in the spectrum of $\left[\mathrm{NBu}_{4}\right]\left[\mathrm{Au}(\mathrm{C} \equiv \mathrm{CPh})_{2}\right]$ and hence should arise from the $\left[\mathrm{Au}_{3}\left(\mu_{2}-\mathrm{dppm}\right)_{2}(\mathrm{C} \equiv \mathrm{CPh})_{2}\right]^{+}$cation. Because the complex $\left[\mathrm{Au}(\mathrm{C} \equiv \mathrm{CPh})\left(\mathrm{PPh}_{3}\right)\right]$ does not show any significant absorption at $\lambda>300 \mathrm{~nm}$ (see also Fig. 2), the broad absorption shoulder in Fig. 2 should arise from weak $\mathrm{Au} \cdots \mathrm{Au}$ interaction, as revealed in the crystal structure. For the analogous trinuclear complex $\left[\mathrm{Au}_{3}\left(\mu_{3}-\mathrm{tpm}\right)_{2}(\mathrm{Cl})\right]^{2+l e}$, extended Huckel molecular orbital calculation has shown that the HOMO is the $d \delta^{*}$ orbital and the LUMO is the $p \sigma$ orbital, which arises from the interaction

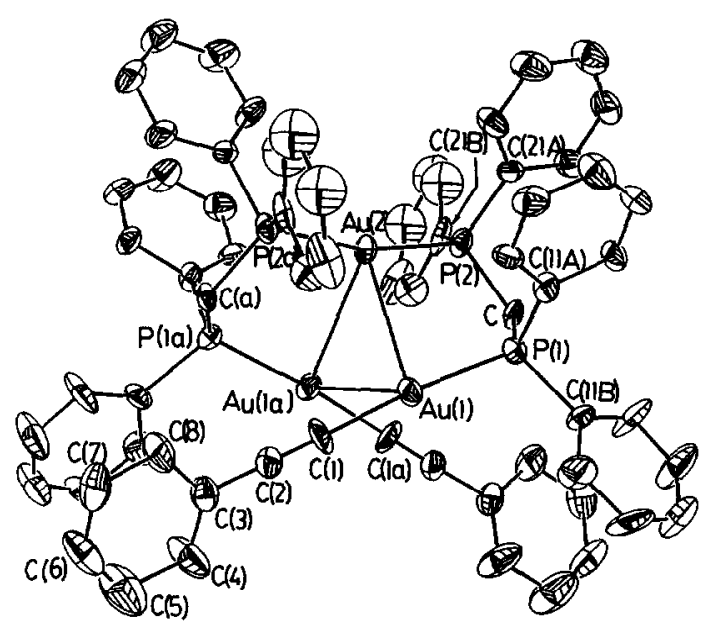

Fig. 1. Perspective view of the $\left[\mathrm{Au}_{3}\left(\mu_{2}-\mathrm{dppm}\right)_{2}\right.$ $\left.(\mathrm{C} \equiv \mathrm{CPh})_{2}\right]^{+}$cation; only the bonded carbon atoms of the dppm phenyls are labelled; the $C_{2}$-related atoms of the coordination sphere are labelled by " $a$ ". of the $6 p$ orbitals of the gold(I) ions. Similarly, the LUMO and HOMO of $\left[\mathrm{Au}_{3}\left(\mu_{2}-\mathrm{dppm}\right)_{2}(\mathrm{C} \equiv \mathrm{CPh})_{2}\right]^{+}$ are expected to be $p \sigma$ and $d \delta^{*}$, respectively, both of which, however, must acquire certain ligand character (phenylacetylide). The 315-375 nm shoulder is tentatively assigned to the $d \delta^{*} \rightarrow p \sigma$ transition.

Both solid state and solution of $\left[\mathrm{Au}_{3}\left(\mu_{2-}\right.\right.$ $\left.\mathrm{dppm})_{2}(\mathrm{C} \equiv \mathrm{CPh})_{2}\right]\left[\mathrm{Au}(\mathrm{C} \equiv \mathrm{CPh})_{2}\right]$ are emissive. Figure 3 shows the emission spectrum of a degassed acetonitrile of the complex. The room temperature emission spectrum is composed of two bands centred at 425 and $\sim 600 \mathrm{~nm}$. The $425 \mathrm{~nm}$ band is more intense than that at $600 \mathrm{~nm}$, and the emission lifetimes are 0.45 and $8.7 \mu \mathrm{s}$, respectively. It is noted that both $\left[\mathrm{Au}\left(\mathrm{PPh}_{3}\right)(\mathrm{C} \equiv \mathrm{CPh})\right]$ and $\left[\mathrm{NBu}_{4}\right][\mathrm{Au}(\mathrm{C} \equiv$ $\mathrm{CPh})_{2}$ ] exhibit intense intraligand $(-\mathrm{C} \equiv \mathrm{CPh})$

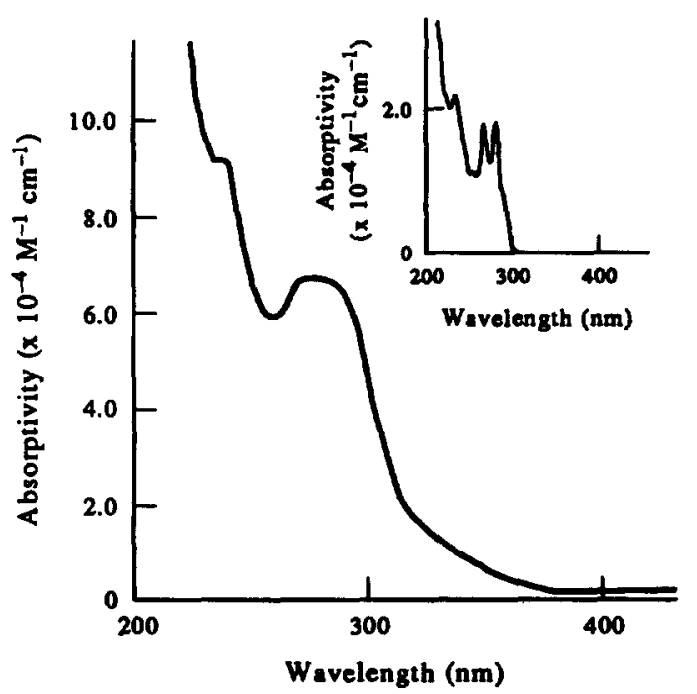

Fig. 2. Room temperature UV-vis absorption spectrum of $\left[\mathrm{Au}_{3}\left(\mu_{2}-\mathrm{dppm}\right)_{2}(\mathrm{C} \equiv \mathrm{CPh})_{2}\right]\left[\mathrm{Au}(\mathrm{C} \equiv \mathrm{CPh})_{2}\right]$ in acetonitrile; inset: absorption spectrum of $\left[\mathrm{Au}\left(\mathrm{PPh}_{3}\right)\right.$ $(\mathrm{C} \equiv \mathrm{CPh})]$ in acetonitrile. 


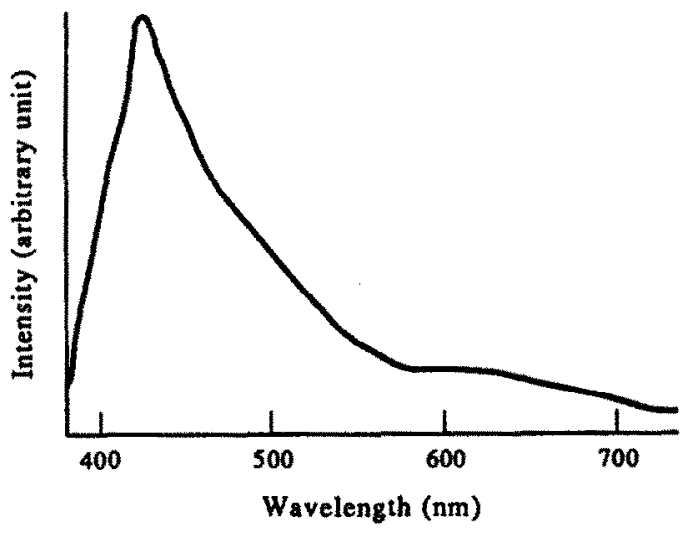

Fig. 3. Emission spectrum of a degassed acetonitrile solution of $\left[\mathrm{Au}_{3}\left(\mu_{2}-\mathrm{dppm}\right)_{2}(\mathrm{C} \equiv \mathrm{CPh})_{2}\right]\left[\mathrm{Au}(\mathrm{C} \equiv \mathrm{CPh})_{2}\right]$ at $298 \mathrm{~K}$.

emission at about $430 \mathrm{~nm}$ at room temperature. ${ }^{5}$ Thus, the $425 \mathrm{~nm}$ emission of $\left[\mathrm{Au}_{3}\left(\mu_{2}-\mathrm{dppm}\right)_{2}\right.$ $\left.(\mathrm{C} \equiv \mathrm{CPh})_{2}\right]\left[\mathrm{Au}(\mathrm{C} \equiv \mathrm{CPh})_{2}\right]$ is logically assigned to come from the anion. The long-lived $600 \mathrm{~nm}$ emission is attributed to come from the trinuclear $\left[\mathrm{Au}_{3}\left(\mu_{2}-\mathrm{dppm}\right)_{2}(\mathrm{C} \equiv \mathrm{CPh})_{2}\right]^{+}$cation and is tentatively assigned to ${ }^{3}\left(d \delta^{*} p \sigma\right)$ emission. The redshift of this emission from the emission spectrum of $\left[\mathrm{Au}\left(\mathrm{PPh}_{3}\right)(\mathrm{C} \equiv \mathrm{CPh})\right]$ is therefore attributed to the weak $\mathrm{Au} \cdots \mathrm{Au}$ interaction in $\left[\mathrm{Au}_{3}\left(\mu_{2}-\right.\right.$ $\left.\mathrm{dppm})_{2}(\mathrm{C} \equiv \mathrm{CPh})_{2}\right]^{+}$.

Acknowledgements - We acknowledge support from the Hong Kong Research Grant Councils and The University of Hong Kong. C. M. C. is grateful for a visiting Professorship administered by the National Taiwan University.

\section{REFERENCES}

1. (a) C. Kutal, Coord. Chem. Rev. 1990, 99, 213 ; (b) P. C. Ford and A. Vogler, Accts Chem. Res. 1993, 26, 220 ; (c) C.-M. Che, H.-L. Kwong, C.-K. Poon and V. W.-W Yam, J. Chem. Soc., Dalton Trans. 1990, 3215; (d) C. King, J. C. Wang, N. I. Md. Khan and J. P. Fackler Jr, Inorg. Chem. 1989, 28, 2145; (e) C.-M. Che, H.-K. Yip, V. W.-W. Yam, P.-Y. Cheung, T.-F. Lai and S.-M. Peng, J. Chem. Soc., Dalton Trans. 1992,427 ; (f) V. W.-W. Yam, C.-M. Che and T.-F. Lai, J. Chem. Soc., Dalton Trans. 1990, 3747; (g) C.M. Che, W.-T. Wong, T.-F. Lai and H.-L. Kwong, $J$. Chem. Soc., Chem. Commun. 1989, 243.

2. G. Jia, R. J. Puddephatt and J. J. Vittal, J. Organomet. Chem. 1993, 449, 211.

3. J. Vicente, M. D. Bermúdez and J. K. Escribano, Organometallics 1991, 10, 3380.

4. D. Li, X. Hong, C.-M. Che, W.-C. Lo and S. M. Peng, J. Chem. Soc., Dalton Trans. 1993, 2929.

5. C. M. Che, unpublished results. 